Ивана Ћирић
Музеј Николе Тесле, Београд
Удк 004:02 Тесла Н.

дОИ https://doi.org/10.18485/

melissa.2016.15.1.ch6

\title{
ВИРТУЕЛНА БИБЛИОТЕКА НИКОЛЕ ТЕСЛЕ
}

\section{Сажетак}

У оквиру оставштине Николе Тесле, у Музеју посвећеном овом научнику се чува и његова лична библиотека. Многи познаваоци ову библиотечку грађу сматрају најзначајнијим делом Теслине оставштине. Најстарија публикација потиче из 1720. године а најмлађа из 1943. Године 2014. Библиотека Николе Тесле је проглашена за културно добро од великог значаја као стара и ретка књига и као таква завређује и адекватну заштиту, првенствено у виду конзервације и рестаурације али и у виду дигитализације. Дигитализацијом монографских публикација из Теслине библиотеке и израдом апликације, Теслине књиге ће бити доступне за претраживање и истраживање. Теслина лична библиотека, тренутно није изложена опасностима од физичких оштећења али постоји оправдана нужност за што хитнијом дигитализацијом и стручном обрадом овог дела фонда. У будућности се планира постављање ове виртуелне библиотеке на веб сајт Музеја чиме ће се трајно и без надокнаде омогућити увид свима заинтересованима у штиво које је научник читао, изучавао и у коме је уживао. Наиме, сматрамо да је у ери технике и дигитализације, неопходно обрадити и представити јавности овако вредно културно добро.

Кључне речи: Никола Тесла, Виртуелно, Библиотека, Културно наслеђе, Стара и ретка књига.

Музеј Николе Тесле је од оснивања замишљен као комплексна институција која има културни, образовно научни и меморијални карактер. Оваква поставка је у великој мери одредила његовупрвобитну визију и мисију. Као институција културе, Музеј се бави заштитом и представљањем Теслине оставштине. Обављају се истраживања, публикују се оригинални Теслини списи а запослени и сарадници Музеја учествују у научним скуповима на којима представљају резултате истраживања. У Музеју се чувају и посмртни остаци Николе Тесле што га чини једним од ретких меморијално - техничких музеја у свету. 
Свеопшта повезаност модерног друштва и изузетна заинтересованост људи широм света, посебно младих, за Теслину личност и дело, данас дају посебан печат првобитно замишљеној друштвеној улози Музеја. Можемо слободно рећи да модерну визију и мисију Музеја дефинишу заједно запослени и заинтересована публика у Србији и свету.

Поред чињенице да је овај Музеј основан као први технички музеј у Југославији, да се у њему чува и обрађује оставштина генијалног проналазача Николе Тесле, он уједно представља установу комплексног типа јер се у њему баштини грађа различитог састава - музејски артефакти, архивска и библиотечка грађа. Ова чињеница условљава сложен процес заштите, обраде и презентације и намеће уску сарадњу између различитих струка. Сарадњу додатно усложавају одређене процедуре предвиђене законима јер закони који регулишу поступање са различитим категоријама културне баштине нису још увек адекватно синхронизовани.

\section{Пут Теслине оставштине из Сједињених Држава у Вилу Генчић}

Залагањем Саве Косановића и његових сарадника, део Теслине оставштине пренет је у Београд као његова лична имовина. Тај део оставштине, спакован у 60 различитих пакета, металних сандука, бачви и кофера пренесен је теретним бродом М/С „Србија“ који је пристигао у луку у Ријеци 30. септембра 1951. Истим бродом, за Југославију је допутовала и Шарлота Мужар, секретарица Саве Косановића, Теслиног сестрића. На броду је упознала господина Еда Барета из „Барет“ транспортне компаније који је био задужен да надгледа транспорт оставштине. Од њега је сазнала да је паковање свих ствари био бесплатан допринос чланова Југословенског Сименс клуба из Њујорка (Циврић 256). Након Ријеке, брод је пристао и у Црној Гори а одатле је овај важан товар возом пребачен у Београд на Електротехнички факултет (Циврић 269). ${ }^{1}$ По наводима музејских

1 Оставштина је пребачена у једну од празних соба (собу бр.80). Радослав Хорват је изјавио да је „...у овој соби било свега петнаест сандука и да су имали рупе, можда је неко гурао руку и узимао нешто или су их појели мишеви у магацину где су стајали..., 
стручњака (Zorić, Đокіс́, і Vujović 479) у моменту када је стигла из Сједињених Америчких Држава, лична заоставштина се састојала од:

1. писаног и на други начин забележеног документарног материјала који је накнадном обрадом разврстан у:

а) архивску грађу (касније назван „Лични фонд Николе Тесле оставштина Николе Тесле“);

б) библиотечки материјал (тзв. „Лична библиотека Николе Тесле“), у оквиру кога се налазе и новински исечци (Теслина Хемеротека);

2. личне и друге предмете који су касније подељени у више музејских збирки.

У просторијама Електротехнички факултета је започето примарно прегледање пристиглих ствари и докумената. На овим пословима је био ангажован професор Александар Дамјановић као и низ других професора и асистената (Циврић 269). Након тога, све ствари су пребачене у Генчићеву вилу, у улицу Пролетерских бригада 51, у јуну 1952. године, јер је Музеју у својству закупца, она уступљена на коришћење. Београдска штампа је ову вилу назвала „једном од најлепших кућа у Београду“ (В 1-8). Без сумње, и данас ова зграда има посебну архитектонску и урбанистичку вредност. У овој вили, је током година било смештено више установа. Од 1939. године ту је био смештен Италијански институт културе, а након рата, Свесловенски комитет. ${ }^{2}$ По исељењу комитета, у зграду се уселио Академски савет ФНР. Уговором о закупу из 1952. године склопљеним између власнице зграде и Музеја, висина закупнине одређена је на основу Уредбе о регулисању висине закупнине за пословне просторије, пошто је зграда у то време третирана као пословна просторија. Иако Уговор о закупу, склопљен са госпођом Даницом Јовановић није пронађен у архивској документацији Музеја, овај Уговор склопљен дана 24. марта 1954. године, помиње се у више дописа упућеним Музеју

2 Допис Музеја упућен Секретаријату за финансије НОО Врачар, бр. 216, од 12.06.1959. године. Допис је упућен поводом примене Закона о национализацији на згради у улици Пролетерских бригада 51 у којој је смештен Музеј Николе Тесле. У овом Допису се наводе подаци који су поменути у тексту. Допис је потписала Деса Крстић, тадашњи секретар Музеја. 
од стране Скупштине општине Врачар и Савезног јавног правобраниоштва. ${ }^{3}$

Зграда је национализована решењем од 10. јула 1959. године а почевши од дана 26.12.1958. постала је друштвена својина. ${ }^{4}$ Нешто касније, 22. фебруара 1962. Решењем Народног Одбора Општине Врачар, она је уступљена Музеју на управљање без накнаде.

Из једног дописа ${ }^{5}$ сазнајемо да је још 1985. године поступак за проглашење објекта као културног добра за трајно чување био у току. Одлуком Скупштине града Београда ${ }^{6}$ Генчићева кућа је проглашена за непокретно културно добро 1987. године. Упис забележбе у катастар непокретности да зграда Музеја има својство културног добра, дозвољен је тек 2012. године. ${ }^{7}$

\section{Оснивање Музеја и отварање за јавност}

На предлог Савета за науку и културу Владе, а на основу члана 80. става 2. Устава ФНРЈ, влада ФНРЈ донела је 5. децембра 1952. годи-

3 Допис Скупштине општине Врачар, Одељења за привреду и финансије, упућен Музеју, бр. 187, од дана 07.06.1965., пошиљаоц доставља податке и детаље у вези са плаћањем закупнине национализоване зграде која је дата на коришћење Музеју Николе Тесле.; Допис Савезног јавног правобраниоштва, бр Р-169/62, од дана 09.06.1962.

4 Правоснажно решење Комисије за национализацију при Народном Одбору Општине Врачар у Београду, Н. бр. 3717 од 10. јула 1959. године.; Допис Музеја Скупитини општине Врачар, бр. 87, од дана 07.07.1965.

5 Допис Завода за заштиту споменика културе града Београда Музеју, бр. 85201, од дана 25.09.1985. Допис је заведен у Музеју 01.10.1985. под бројем 359. у истом допису је констатовано да је потребно извршити одређене радове а списак достављен у прилогу наводи хитне интервенције првенствено у погледу поправки постојећих балустера, израду калупа за изливање нових, бојење балустера, поправку и чишћење терасе, поправку лимених опшивки каозаштита од воде и чишћење и заливање оштећених спојница на згради.

6 Одлука Скупштине града Београда о допунама одлуке о проглашењу одређених непокретности на територији града Београда за културна добра, бр. 6-488/87XXIX-01 од 9. јула 1987. године. Границу непосредне околине која је заштићена чине спољне ивице катастарске парцеле бр. 43/1, 43/2, ЗКУЛ бр. 277, КО Врачар - општина Врачар. Објављено у Службеном листу града Београда бр. 16/87.

7 Делимично Решење Републичкоггеодетскогзавода, Службазакатастарнепокретности Београд, Република Србија, бр. 952-02-14153/11, од дана 17.12.2012. На основу захтева који је поднео Завод за заштиту споменика културе града Београда, Служба за катастар непокретности Београд, донела је Делимично Решење којим се дозвољава овај упис. 
не Решење о оснивању Музеја Николе Тесле. Ово решење потписао је Јосип Броз Тито. Решење је објављено у Службеном листу ФНРЈ, бр. 59 од 10. децембра 1952. године. ${ }^{8}$ Исте године, за првог директора је изабран професор Филозофског Факултета Вељко Кораћ. Годину дана касније, 15. априла 1953. године изабран је и први саветодавни одбор Музеја у саставу: Сава Косановић, Вељко Влаховић (директор Борбе), Божидар Краут, Александар Дамјановић, Илија Обрадовић, Јосип Лончар и Милан Видмар (Циврић 20).

Након оснивања Музеја и сређивања материјала започете су припреме за изведбу сталне поставке које су трајале у периоду од 1953. до 1955. године. Пројекат преуређења приземља Генчићеве виле је 1955. године урадио архитекта Слободан М. Васиљевић Мацуока, студент професора Николе Брашована. Организовањем приземља у три целине, повезане кружним током, коришћењем сведене геометрије, увођењем контраста плафонских и зидних облога успео је да оствари утисак озбиљности изложбеног простора а уједно и да се значајно афирмише као архитекта. ${ }^{9}$

У изради сталне поставке је учествовао цео тим професора са Електротехничког факултета на челу са директором новооснованог Музеја (Циврић 30). Истраживање музејске грађе, ради избора за поставку радних модела према Теслиним замислима било је поверено инжењеру (касније професору) Јовану Сурутки као и израда пратећих текстова и смишљање концепције оног дела поставке који је био посвећен Теслиним открићима (Циврић 60). Израда експоната је поверена Институту САН за испитивање електричних појава „Никола Тесла“. Почетком децембра, 1953. године Музеј је послао Институту наруџбину за израду модела. Институт је израдио 11 од укупно 15 модела а остали модели су израђени на Електротехничком факултету и у Војнотехничком институту Југословенске армије. Сви модели су израђени и испоручени за годину и по дана . (Циврић 136,137).

Музеј Николе Тесле у Београду је отворен за јавност 20. октобра 1955. године и био је први технички музеј у Југославији. Овом приликом представљена је стална поставка на којој су посетиоци мог-

\section{Исто, 17, 21.}

Изузетак је просторија у којој је стајала урна са посмртним пепелом. 
ли посматрати моделе израђене по Теслиним нацртима. Отварању су присуствовале многе познате личности из света науке и културе а између осталих и Моша Пијаде (тада председник Савезне народне скупштине), Петар Стамболић (председник народне скупштине Србије), Родољуб Чолаковић (потпредседник Савезног извршног већа), Милентије Поповић, Мијалко Тодоровић и Сава Косановић (чланови Савезног извршног већа), Милош Минић (председник Народног одбора среза Београда) и Ђуро Салај (председник Савеза синдиката Југославије). Свечаном отварању присуствовао је и тадашњи амерички амбасадор у Београду, Џемс Ридлбергер (Борба, Политика 7). Уводни говор одржао је Вељко Кораћ.

Музеј данас представља јединствену институцију науке и културе у Србији, као и у свету. Једини је музеј који чува оригиналну и личну заоставштину Николе Тесле. Поседује изузетно вредне колекције:

- преко 160.000 оригиналних докумената;

- преко 7000 књига и часописа;

- преко 1200 историјско-техничких експоната;

- преко 1500 фотографија и стаклених фотоплоча оригиналних техничких предмета, инструмената и уређаја;

- преко 1000 планова и цртежа.

\section{Теслина библиотека - Стара и ретка књига -} - културно добро од великог значаја

Библиотечки фонд Музеја чине две одвојене целине. Прву целину чини Лична библиотека Николе Тесле док другу чини Музејска библиотека. Иако су ове целине физички одвојене, повезује их иста тематика и органска припадност. У оквиру обе целине се чувају публикације које се углавном тичу живота и рада Николе Тесле или су одраз његових интересовања.

У члану бр. 26. Закона о културним добрима (Стаматовић 120) (Стара и ретка књига) наводи се: Стару и ретку књигу сачињавају: рукописи, рукописне и итампане књиге, периодика и друга библиотечка грађа настала до краја 1867. године, ретке књиге, одређени 
примерци периодичних издања и друге ретке библиотечке грађе настале и после ове године, одређена библиотечка грађа која се на основу овог закона доставља овлашћеној библиотеци као обавезни примерак и документација о њој, као и посебне библиотечке целине које су због свог садржаја, уметничке, културне и историјске вредности значајне за науку и културу.

На основу ову закона а на предлог тадашње управе, упућен Народној библиотеци Србије упућен је допис дана 7. марта 2014. године, ${ }^{10}$ са молбом да се Лична библиотека Николе Тесле прогласи за културно добро од великог значаја као стара и ретка књига. Одлуку о утврђивању старе и ретке библиотечке грађе за културно добро од великог значаја донео је Управни одбор Народне библиотеке Србије 18. марта 2014. године (Службени гласник 48).

У погледу превентивне заштите овог фонда оставрени су одређени кораци. Периодика и хемеротечка грађа су смештене у посебне комере са климатском регулацијом. Монографске публикације су одложене у витрине израђене од стакла и дрвета без посебне климатске регулације обзиром да су у релативно добром стању. Увиђајући све већи значај конзервацијских радова, у току 2014. је оформљена конзерваторска радионица од укупно $12 \mathrm{~m}^{2}$ са посебним столовима и једном комором у којој су смештене хемијске и остале супстанце које се користе у третманима конзервације.

\section{Монографске публикације}

Монографске публикације из Теслине библиотеке не представљају обиман фонд, међутим, по свом садржају овај фонд је врло занимљив и значајан, не само због чињенице да је његов творац један од најзначајних научника који је икада живео већ и због тога што представља богат извор информација за научнике и истра-

10 Допис Музеја Народној библиотеци Србије, бр. 35/2014. У прилогу Предлога, достављена је биографија Николе Тесле, текстуални преглед садржаја књижног фонда и табела са насловима свих штампаних докумената које чине Личну библиотеку Николе Тесле. 
живаче који изучавају живот и стваралаштво Николе Тесле као и за све историчаре науке. Ова целина је врло разнолика и по садржаају и по облику. У оквиру ње се налазе бројна књижевна дела, речници, неке енциклопедије али и инжењерски приручници, научне расправе и сепарати. Иако је доста наслова на српском језику, ипак више од $80 \%$ фонда је на страним језицима. Ту се налазе публикације на немачком, француском, италијанском... али највећи део чине оне на енглеском језику, чак 70\% од укупног броја публикација.

\section{Серијске публикације}

Као и у књижном фонду Теслине библиотеке и међу часописима и новинама се може наћи широк спектар садржаја. Тесла је читао и сачувао бројне примерке стручних и референтних часописа и магазина (Electrician, Electrical Review...) али и оних који су у то време били популарни, као што су политички, географски, спортски, забавни и хумористички. Неки наслови часописа и магазина који се чувају у Музеју су:

ADVENTURE (популарна америчка литература), AMERICA (римо-католичка црква), ARHIV za hemiju i tehnologiju, ARMY and Navy Journal, AUTO-MOTOR Journal, БЕОГРАДСКЕ општинске новине, БРАНКОВО коло, COLLEGE Humor, CURRENT Literature (друштвени живот САД-а), ДЕЧИЈЕ новине, ГЛАС Српске краљевске академије, HEALTH Culture, JUGOSLAVENSKA narodna privreda, JUNGGESELLE (немачка књижевност), LEBEN (фотографије), MOTION Picture Magazine (филм), MOTOR Life (аутомобилизам), DIE Muskete (хумор), NARODNO kolo, HАША домовина, NOVA Jugoslavija, OPEN Court (филозофија религије), OXFORD Magazine, PEARSON'S Magazine (друштвена питања), PHYSICAL Culture, PRIRODA, PREGLĄD teletechniczny (електротехника), PSYCHOLOGY, READER'S Digest, RED Book Magazine (америчка књижевност), RIVISTA tecnica d’elettricità, ROTARIAN, SANSGÊNE (хумор), СОКО (соколски покрет), SOVIET Russia Today, СРПСКA отаџбина, СРПСКО огледало (српски емигранти у САД-у), ТЕНNIČКІ list, THEATRE Magazine (позориште), THINKER (филозофија), THIS Week 
(разонода),TOWN Topics (друштвени живот Њујорка), UMSCHAU (природне науке), VIE Parisienne (хумористички), VOIX de I'humanité (политички) и WASTE Basket (омладински часопис).

\section{Хемеротечка збирка}

Док преко књига и часописа које је Никола Тесла поседовао можемо да судимо о његовим интересовањима на пољу науке и о књижевном укусу, исечци нам омогућавају увид у друштвени живот, на какав је одзив наилазио у јавности али и у стручним круговима. 3бог своје изузетне важности, исечци из новина и часописа се третирају као посебна целина овог Фонда (Теслини новински исечци - Хемеротечка збирка).

Колекција новинских исечака и новина из личне заоставштине Николе Тесле се састоји од неколико различитих делова који су разврстане по следећим категоријама:

1. Укоричени албуми са исечцима,

2. Исечци који нису укоричени,

3. Листови из новина на којима су обележени чланци за исецање,

4. Необележени листови и

5. Цели примерци новина.

Укоричени исечци се налазе у посебним албумима, ${ }^{11}$ па су тиме и делимично заштићени. Евидентна је ургенција за приступ обради исечака који нису укоричени, дакле оних који припадају целинама 2-5. Наиме, новинска хартија је нарочито подложна пропадању њен век се процењује на око 50 година - а неки исечци потичу с краја 19. века. Чланци из часописа из овог дела фонда, су у бољем физичком стању, пошто су штампани на квалитетнијој хартији. До сада је мањи број исечака рестаурисан, и то су углавном они чланци који се налазе у укориченим албумима.

Већи степен хитности завређују они чланци које је Тесла обележио а који још увек нису издвојени из новина као и оних који нису

11 Нужно је разликовати исечке од чланака. У албумима се наилази на ситуације када неколико исечака, физички одвојених, чине један чланак. Зато говоримо о броју исечака који износи око 23.000 и броју чланака који износи око 20.000. 
обележени а зацело се налазе међу сачуваним Теслиним новинама. Не зна се ни оквирни број ових чланака јер су сви новински листови и новине тренутно заштићени посебним конезрватосрким поступцима и херметички затворени у кесе намењене посебно за осетљиву новинску хартију.

Имајући у виду да је основни циљ дигитализације Хемеротеке омогућавање оригиналних докумената за конзервацију и трајно чување како би се подржало истраживање, омогућила издавачка делатност и будуће коришћење у научне и истраживачке сврхе, без опасности од уништења, формулисано је неколико основних фаза у оквиру процеса дигитализације овог дела Теслине Хемеротеке:

1. припремни преглед,

2. додељивање ознака странама из албума,

3. скенирање,

4. обрада добијених дигиталних слика и

5. исецање новинских чланака.

\section{Дигитализација као вид заштите}

Према ИФЛА/УНЕСКО Манифесту за дигиталне библиотеке из 2011. године (IFLA), дигитализација комплетног културног наслеђе представаља област од стратешког значаја, не само за библиотеке, музеје и архиве већ и за све остале заштитарске институције и од изузетне је важности да јој се приступи са посебном пажњом.

Музеј Николе Тесле је у току свог постојања реализовао многе значајне пројекте. Један од најважнијих је пројекат под називом "Дигитализација Теслине Архиве“. Овај пројекат је трајао више година, од 2007. до 2013. године. У току трајања пројекта дигитализовано је око 166.000 Теслиних докумената који припадају архивској грађи. На пројекту је радило десет стручних сарадника - архивисти, кустоси, оператери и саветници.

Наредни, значајан пројекат под називом „Микрофилмовање Теслине Архиве“" трајао је нешто више од годину дана у периоду од почетка 2013. до средине 2014. У току трајања пројекта, целокупна 
Теслина оставштина архивских докумената је микрофилмована и спакована у посебан орман за то намењен. Такође су израђене и друга копија микрофилмоване архиве. У пројекту је учествовало осам стручних сарадника - архивиста, кустоси и друга стручна лица.

Након што је први пут 2009. године, у оквиру истраживања студената са Природно-математичког факултета из Београда, извршена дигитализиција прва два албума новинских исечака, у новембру 2012. године, на иницијативу тадашњег заменика директора Музеја Младена Вујовића, а у сарадњи са фирмом «ДАС», која је у то време била једна од водећих у Србији у области пружања техничке подршке у процесима скенирања, Музеј је започео дигитализацију једног дела Хемеротеке Николе Тесле, која је приведена крају 2014. године. Овим поступком је завршено скенирање једног дела Теслине хемеротеке који укључује 57 укоричених албума.

У току 2016. године, захваљујући донацији Министарства културе и информисања и конкурса за финансирање и суфинансирање пројеката из области ДИГИТАЛИЗАЦИЈЕ КУЛТУРНОГ НАСЛЕЪА у 2016. години, Музеј је добио одређена средства за започињање пројекта "Дигитализација монографских публикација из личне библиотеке Николе Тесле". Пројекат се у првом реду односи на дефинисање и имплементацију дигиталних метода и техника у реалзацији дигиталне библиотеке. Такође, односи се на унапређење дигиталних метода и техника за пописивање, чување, представљање и анализу културног наслеђа и на обезбеђивање системског, квалитетног и уједначеног приступа дигитализованој грађи у установама заштите уз поштовање међународно признатих стандарда. Све активности на пројекту имају за циљ проучавање и валоризацију старе и ретке библиотечке грађе које се чува у Музеју Николе Тесле у посебном делу фонда.

Значај овог пројекта се првенствено огледа у започињању комплексног процеса рада на заштити регистрованог културног добра од великог значаја у виду дигитализације, стручне обраде и анализе публикација чиме би се значајно допунила постојећа сазнања о Николи Тесли. Такође, његов посебан значај за човечанство представља и презентација резултата и дељења са другима путем публикованог материјала а када технички услови буду задовољени планира се и увођење слободног приступа за преглед подацима о Теслиним књигама. 
Библиотечку грађу многи проучаваоци сматрају најзначајнијим делом фонда управо због тога што се у оквиру ње чува материјал који је и сам Тесла користио за истраживање и читање. Опште физичко стање монографских публикација из Теслине личне библиотеке је врло задовољавајуће уколико узмемо у обзир врсту материјала (новински папир, каширани картон и кожа) и његову старост (преко 120 година). Теслине књиге се чувају у посебној витрини па су заштићене од спољних утицаја а просторија у којој се оне налазе је под сталним видео надзором. У неколико наврата најугроженије књиге су подвргнуте конзерваторским третманима. Ове третмане су вршили стручни конзерватори у Архиву Србије и у посебној радионици која се налази у оквиру депоа Музеја. На појединим књигама постоје видљиви трагови коришћења, посебно на корицама и рикнама али они нису дубоки и по стручној препоруци, нису били подвргнути посебним конзерваторским третманима како се не би нарушавала аутентичност њиховог изгледа. Процес конзервације није комплетиран али се књиге шаљу на конзервацију сукцесивно, када то услови дозвољавају или се за то укаже потреба.

Највећи део публикација је дигитализован и обрађен у току 2016. године. Наставак и завршетак пројекта је планиран за крај 2017. године уколико Министарство буде подржало наставак активности на пројекту. Крајњи исход пројекта је да омогући приступ квалитетно презентованој дигиталној грађи што ће значајно допринети новим сазнањима и дати увид у још један сегмент живота и рада Николе Тесле.

Како се Теслине књиге сматрају врло вредним делом библиотечког фонда, целокупан подухват њихове обраде добија додатну важност и ургентност. Не само због чињенице да обрада овог фундуса спада у делатност Музеја већ и због нових података до којих би се без сумње дошло. Комплетираном дигитализацијом ових књига, Музеј би могао да приступи још једном сличном пројекту - дигитализацији часописа из Теслине личне библиотеке. Тек након реализације и овог пројекта могло би се приступити и изради Виртуелне библиотеке Николе Тесле што представља уједно и крајњи циљ свих корака предузетих до сад. 


\section{Литература:}

B.J. „Теслина заоставштина налази се у нашој земљи“ Борба, 15. јул 1952: 1 и 8. Print. Zorić, Ivana, Đокіć, Aleksandar i Vujović, Mladen. „Informatizacija rada Muzeja Nikole Tesle, kao kompleksne ustanove zaštite kulturnih dobara“. Tehnični in vsebinski problemi klasičnega in elektronskega arhiviranja, 9. zbornik referatov dopolnilnega izobraževanja s področij arhivistike, dokumentalistike in informatike v Radencih. Ured. Slavica Tovšak. Slovenija: Maribor: Pokrajinski arhiv Maribor, 2010. Print.

IFLA. „IFLA/UNESCO МАНИФЕСТ ЗА ДИГИТАЛНЕ БИБЛИОТЕКЕ“. IFLA. http://www. ifla.org/files/assets/digital-libraries/documents/ifla-unesco-digital-librariesmanifesto-sr.pdf Web (преузето 1.3.2016.)

Службени гласник број 34. 26. март 2014. Print.

Стаматовић, Десанка. Читалишта у Србији у XIX веку. Београд: Народна библиотека Србије, 1984.

„Теслина бајка“ Политика, 21. октобар 1955: 7. Print.

„Теслин Музеј у Београду“ Борба, 22. октобар 1955. Print.

Циврић, Зорица уред. Музеј Николе Тесле 1952-2003. Београд: Музеј Николе Тесле, 2004. Print.

\section{Ivana Ćirić}

\section{NIKOLA TESLA VIRTUAL LIBRARY}

\section{Summary}

As a part of the Nikola Tesla Legacy, the Museum dedicated to the scientist keeps his personal Library. Many experts consider this Library as the most important part of Tesla's Legacy. The oldest publication dates from 1720 and the youngest from 1943. In 2014, the Library of Nikola Tesla was declared as a Cultural Heritage of great importance as an old and rare book and as such it deserves an adequate protection, primarily in the form of conservation and restoration but as well in the form of digitization. By digitalization of books from Tesla's personal Library and by creating a custom software application, Tesla's books will be available for browsing and research. At this moment Tesla's personal Library is not exposed to risks arising from physical damage but there is a demonstrable need for the urgency of digitization and of processing this part of the fund. 
It is planned to set this virtual library on the Museum web site, which will permanently and without compensation make Tesla's books available to everyone interested in material that scientist read, studied and in which he enjoyed. Specifically, we believe that it is necessary in the era of technology and digitization, to process and present to the public such worthy cultural heritage.

Key words: Nikola Tesla, Virtual, Library, Cultural Heritage, Old and Rare Book. 